\title{
$\mathrm{H}_{2} \mathrm{O}$ 로 발포된 멜라민포스페이트-폴리우레탄폼 복합체 합성과 열적 특성 분석
}

\author{
박경규·이상호 \\ 동아대학교 화학공학과 \\ (2013년 12월 11일 접수, 2014년 3월 12일 수정, 2014년 3월 20일 채택)
}

\section{Synthesis of Melamine Phosphate-Polyurethane Composite Foam Blown by Water and Characterization of Its Thermal Properties}

\author{
Kyeong-Kyu Park and Sang-Ho Lee \\ Department of Chemical Engineering, Dong-A University, Hadan2-dong, Saha-gu, Busan 604-714, Korea \\ (Received December 11, 2013; Revised March 12, 2014; Accepted March 20, 2014)
}

\begin{abstract}
초록: 멜라민포스페이트(MP)가 분산된 폴리우레탄폼 복합체(MP-PUF)를 만들고, MP-PUF의 모폴로지, 독립기포율, 열전도율, 열분해온도 등을 분석하였다. MP-PUF는 MP가 분산된 폴리아디페이트디올 $(f=2)$, 폴리에테르-폴리올 $(f=4.6)$ 과 $\mathrm{PMDI}(f=2.5)$ 를 원료로 사용하고 발포제로 $\mathrm{H}_{2} \mathrm{O}$ 양을 변화시키며 제조하였다. 폴리우레탄폼의 $\mathrm{MP}$ 함량은 $1.43 \pm 0.30 \mathrm{wt} \%$ 로 고정하였다. $\mathrm{H}_{2} \mathrm{O}$ 의 양이 증가할수록 순수한 폴리우레탄폼(PUF)의 열전도율은 낮아지고 MP-PUF 의 열전도율은 커졌다. PUF와 MP-PUF의 열안정성은 $\mathrm{H}_{2} \mathrm{O}$ 양이 $5 \mathrm{php}$ 에서 최대가 되었다가 그 이상에서는 낮아졌 다. 특히, MP-PUF는 발포과정에 생성된 우레아기와 MP의 영향으로 열안정성이 크게 향상되어 MP-PUF의 잔량이 $50 \%$ 가 되는 온도가 $370 \sim 450{ }^{\circ} \mathrm{C}$, 잔량이 $30 \%$ 가 되는 온도는 $700{ }^{\circ} \mathrm{C}$ 이상으로 $\mathrm{PUF}$ 에 비하여 각각 $25,70{ }^{\circ} \mathrm{C}$ 이상 높아졌다.
\end{abstract}

\begin{abstract}
Polyurethane/melamine phosphate composite foam (MP-PUF) was prepared from poly(adipate)diol/melamine phosphate composite $(f=2)$, polyether-polyol $(f=4.6)$, and PMDI $(f=2.5)$. The thermal properties of MP-PUF such as morphology, closed-cell content, thermal conductivity, and thermal stabilities were characterized. Water was used as a blowing agent, and the composition of melamine phosphate (MP) was maintained at $1.43 \pm 0.3 \mathrm{wt} \%$ of MP-PUF. As the content of water increased, the thermal conductivity of pure polyurethane foam (PUF) decreased, whereas the thermal conductivity of MP-PUF increased. The thermal stabilities of the PUF and the MP-PUF were maximized at 5 php $\mathrm{H}_{2} \mathrm{O}$, and then decreased at the higher $\mathrm{H}_{2} \mathrm{O}$ contents. The thermal stabilities of MP-PUF were greatly enhanced due to the synergetic effect of MP and urea, which was generated during the blowing process. The temperature of $50 \%$ residual mass of MP-PUF increased to $370 \sim 450{ }^{\circ} \mathrm{C}$ and the temperature of $30 \%$ residual mass exceeded over $700{ }^{\circ} \mathrm{C}$. Compared to the PUF, the temperature of $50 \%$ residual mass and $30 \%$ residual mass were higher than 25 and $70{ }^{\circ} \mathrm{C}$, respectively.
\end{abstract}

Keywords: polyurethane foam, melamine phosphate, composites, themal conductivity, thermal stabilities.

\begin{abstract}
서 론
폴리우레탄폼은 단열특성이 우수하고 가벼울 뿐만 아니라 무기단열재에 비하여 생산공정이 간단하고 가격이 저렴하여, 건물의 단열재나 열관의 보온제로 오랫동안 사용되고 있다. ${ }^{1,2}$ 폴리우레탄폼은 위와 같은 장점들을 가지고 있으나 주성분이 가연 성분이기 때문에 무기소재에 비하여 열안정성과 난연성 이 좋지 않아 이를 보완하기 위한 연구가 진행되어 왔다. 이 런 연구를 소개하자면, Lim 등은 관능기 수가 다른 polypro-
\end{abstract}

${ }^{\dagger}$ To whom correspondence should be addressed.

E-mail: sangho@dau.ac.kr pylene glycol( $f=3 \sim 6)$ 을 사용하여 폴리우레탄폼을 제조하고 열 전도율 등의 특성들을 보고하였다. ${ }^{3}$ 또한 그들은 $\mathrm{OHV}$ (수산 화값)가 서로 다른 폴리올들을 사용하여 폴리우레탄폼을 제 조하고 그 열적 특성을 분석하여, OHV가 높은 폴리올을 사 용할수록 폴리우레탄폼의 열전도율은 낮아진다고 보고하였 다. ${ }^{4}$ 위와 같이 순수한 폴리우레탄폼의 열적 특성에 대한 연 구 이외에도, 폴리우레탄폼 제조 과정에 첨가물을 혼합하여 열적 특성을 개선시킨 연구가 수행되었다. 예로써, Kim 등은 dimethylol butanoic acid를 사용하여 나노클레이(Cloisite $30 \mathrm{~B}$ )를 박리시키고 propylene oxide polyol, PMDI과 함께 제 조한 폴리우레탄폼의 열전도율이 감소하는 반면에 유리전이 온도와 열분해온도는 증가한다고 보고하였다. ${ }^{5} \mathrm{Seo}$ 등은 나 
노클레이와 PMDI를 혼합하여 초음파로 처리한 후에 폴리올 과 반응시켜 제조한 폴리우레탄폼 복합체의 특성을 측정한 결과, 나노클레이의 함량이 증가할수록 열전도율은 낮아지고 난연성은 개선된다고 보고하였다. ${ }^{6}$ Saha 등은 나노클레이와 $\mathrm{TiO}_{2}$, carbon nanofiber와 같은 나노입자를 PMDI에 투입하여 초음파처리와 함께 호모게나이저(homogenizer)로 분산시킨 후에 폴리올과 반응시켜 폴리우레탄폼을 제조하고 열중량분 석을 수행한 결과, 나노입자가 분산된 폴리우레탄폼 복합체 가 순수한 폴리우레탄폼보다 열안정성이 우수하다고 발표하 였다. 나노 물질 외에 인계화합물을 첨가하여 폴리우레탄폼 복합체를 제조하고 열적 특성을 분석한 연구도 있다. Kim 등 은 tetramethylene bis(orthophosphate)와 urea를 반응시켜 tetramethylene bis(orthophosphoryurea)를 합성하고, 폴리우레 탄폼 제조 과정에 첨가하여 폴리우레탄폼의 열적 특성을 개 선시켰다. ${ }^{8}$ Lorenzetti 등은 ammonium polyphosphate, dimethylpropanphosphonate, aluminium phosphinate, triethylphosphate와 같은 여러 가지 인계난연제를 첨가하여 폴리우레탄 폼을 제조하고 열적 특성을 분석하였다. ${ }^{9}$ Park 등도 유기나노 클레이가 박리된 폴리아디페이트 디올에 phenyl polyoxyalkenyl phosphate를 첨가하여 폴리우레탄폼을 제조하고 열적 특성을 분석하여, 폴리우레탄폼 내에 phenyl polyoxyalkenyl phosphate의 함량이 증가할수록 그 열안정성이 개선되는 것 을 보고하였다. ${ }^{10}$

본 연구에서는 폴리우레탄폼에 난연성을 부여하기 위하여 멜라민포스페이트(MP)를 도입하고, 발포제로 $\mathrm{H}_{2} \mathrm{O}$ 를 사용하 여 멜라민포스페이트-폴리우레탄폼 복합체(MP-PUF)를 제조 하였다. 또한 MP가 분산되지 않은 순수한 폴리우레탄폼(PUF) 과 MP-PUF의 모폴로지, 밀도, 열전도율, 열분해 특성에 $\mathrm{H}_{2} \mathrm{O}$ 와 MP가 주는 영향을 분석하였다. MP-PUF는 MP를 폴리아 디페이트디올 합성 과정에서 분산시켜서 MP가 균일하고 안 정하게 분산된 MP-폴리아디페이트디올을 합성하고, 이를 사 용하여 제조하였다.

\section{실 험}

재료. PUF와 MP-PUF 복합체 제조에 사용된 폴리아디페 이트디올은 아디프산(AA)과 디에틸렌글리콜(DEG)을 사용하
여 합성하였다. 폴리에테르-폴리올(SC-455)은 국도화학에서 구입하였으며 MP는 유니버셜 켐텍에서 구입하였다. 폴리올 은 진공오븐을 사용하여 $90^{\circ} \mathrm{C}$ 에서 24 시간 건조시켜 사용하 였다. Polymeric 4,4-diphenylmethane diisocyanate(PMDI)는 Kumho Mitsui Chemicals사의 제품을 사용하였다. 발포제로 증류수 $\left(\mathrm{H}_{2} \mathrm{O}\right)$ 를 사용하였으며 실리콘계 계면활성제로 L-6900 을 사용하였다. 폴리우레탄폼 복합체 발포에 사용한 촉매인 $N, N$-dimethylcyclohexylamine(순도 $99 \%+$ )은 Sigma Aldrich 에서 구입하였다. Table 1에 실험에 사용한 원료의 물리 화 학적 특성을 정리하였다.

폴리아디페이트디올 합성. 폴리아디페이트디올에 MP 입자 를 균일하게 분산시키고, 분산안정성을 오랜 기간 유지하기 위하여 $\mathrm{AA}$ 와 $\mathrm{DEG}$ 로부터 폴리아디페이트디올을 합성하는 초기 과정부터 아래와 같이 전처리 과정을 수행하였다. 반응 기에 $\mathrm{DEG}$ 와 입자상의 $\mathrm{MP}$ 를 투입한 후 $110^{\circ} \mathrm{C}$ 까지 가열하 고 호모게나이저와 초음파 분산기(ultrasonicator)를 사용하여 2시간 동안 교반하였다. MP의 분산 전처리 과정이 끝난 후 에 반응기의 온도를 $150{ }^{\circ} \mathrm{C}$ 로 승온시켰다. $\mathrm{DEG} 1$ 몰당 0.5 몰의 $\mathrm{AA}$ 를 투입하고 $\mathrm{AA} 1$ 몰당 $0.005 \mathrm{~mol}$ 의 촉매( $p$-toluene sulfonic acid)를 투입하여 에스테르 반응을 수행하였다. 반응 온도는 $150 \pm 1.5^{\circ} \mathrm{C}$ 로 유지시켰다. $2 \sim 4 \mathrm{psig}$ 압력의 $\mathrm{N}_{2}$ 를 반 응기에 계속 투입하고 Dean stark을 사용하여 에스테르 반응 중에 생성된 물은 제거하여 정반응을 유도하였다. 반응 중에 반응기 내의 반응/생성 혼합물의 산가를 측정하여 반응진행 정도를 확인하였으며 산가가 변하지 않는 시점에서 반응을 종료하였다. 반응 종료 시에 $\mathrm{AA}$ 의 전환율은 $99 \%$ 보다 높게 측정되었다. MP가 함유되지 않은 폴리아디페이트디올의 경 우 $\mathrm{MP}$ 의 전처리 과정 없이 $\mathrm{DEG}$ 와 $\mathrm{AA}$ 만으로 에스테르 반 응을 수행하였다.

폴리우레탄폼 제조와 분석. MP-PUF 복합체의 제조는 2단 계로 이루어진다. 첫 번째 단계에서 플라스틱 용기에 MP가 분산된 폴리아디페이트디올과 폴리에테르-폴리올(SC-455), $\mathrm{H}_{2} \mathrm{O}(2.3 \sim 9.0 \mathrm{php}$ ), 실리콘 계면활성제(L-6900)를 투입하고 고 속교반기를 사용하여 $1000 \mathrm{rpm}$ 에서 60 초간 혼합하였다. 두 번째 단계로, 혼합 과정이 끝난 상태의 폴리올 혼합물에 polymeric 4,4'-methylenediphenyl diisocyanate(PMDI)와 촉매 를 투입하고 $3000 \mathrm{rpm}$ 에서 30 초간 반응시켜 MP-PUF 복합

Table 1. Chemical and Physical Properties of the Raw Materials

\begin{tabular}{|c|c|c|c|c|c|}
\hline Substance & $\begin{array}{l}\text { Hydroxyl value } \\
(\mathrm{mgKOH} / \mathrm{g})\end{array}$ & $\begin{array}{l}\text { Equivalent } \\
\text { wt. (g) }\end{array}$ & $\begin{array}{l}\text { No. of functional } \\
\text { group }\end{array}$ & $\begin{array}{c}\text { Viscosity } \\
\text { at } 25^{\circ} \mathrm{C} \text { (cps) }\end{array}$ & Remarks \\
\hline Poly(adipate)diol & 366 & $153^{b}$ & 2.0 & 450 & \\
\hline Poly(adipate)diol with $\mathrm{MP}^{a}$ & 280 & $200^{b}$ & 2.0 & 780 & MP content $5 w t \%$ \\
\hline Polyether-polyol (SC-455) & 450 & $125^{b}$ & 4.6 & 5700 & \\
\hline $\mathrm{PMDI}^{d}$ & - & $126^{c}$ & 2.5 & 290 & \\
\hline
\end{tabular}

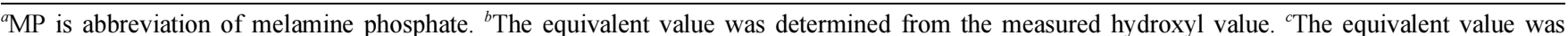
determined from the measured $\mathrm{NCO} \%$. ${ }^{d}$ Polymeric 4,4'-methylenediphenyl diisocyanate. 
Table 2. Formulations Used to Prepare MP-Polyurethane Foam Composites

\begin{tabular}{cccccccc}
\hline $\begin{array}{c}\text { Sample } \\
\text { No. }\end{array}$ & $\begin{array}{c}\text { Poly(adipate)diol } \\
(\text { wt\%) }\end{array}$ & $\begin{array}{c}\text { SC-455 } \\
(\text { wt\%) }\end{array}$ & $\begin{array}{c}\text { MP } \\
(\text { wt\%) }\end{array}$ & $\begin{array}{c}\text { PMDI } \\
(\text { wt\%) }\end{array}$ & $\begin{array}{c}\text { L-6900 } \\
(\text { wt\%) }\end{array}$ & $\begin{array}{c}\text { Catalyst }^{a} \\
(\text { wt\%) }\end{array}$ & $\begin{array}{c}\mathrm{H}_{2} \mathrm{O} \\
(\text { wt\%/php) }\end{array}$ \\
\hline PUF1 & 28.84 & 9.39 & - & 59.62 & 0.57 & 0.69 & $0.88 / 2.3$ \\
PUF2 & 26.49 & 8.63 & - & 62.49 & 0.53 & 0.63 & $1.23 / 3.5$ \\
PUF3 & 24.04 & 7.83 & - & 65.48 & 0.48 & 0.57 & $1.59 / 5.0$ \\
PUF4 & 21.41 & 6.97 & - & 68.69 & 0.42 & 0.51 & $1.99 / 7.0$ \\
PUF5 & 19.29 & 6.28 & - & 71.28 & 0.38 & 0.46 & $2.30 / 9.0$ \\
\hline MP-PUF1 & 34.49 & 8.16 & 1.72 & 55.06 & 0.61 & 0.74 & $0.94 / 2.3$ \\
MP-PUF2 & 31.50 & 7.46 & 1.58 & 58.50 & 0.56 & 0.67 & $1.31 / 3.5$ \\
MP-PUF3 & 28.42 & 6.72 & 1.42 & 62.05 & 0.50 & 0.61 & $1.69 / 5.0$ \\
MP-PUF4 & 25.14 & 5.95 & 1.26 & 65.84 & 0.45 & 0.54 & $2.09 / 7.0$ \\
MP-PUF5 & 22.54 & 5.33 & 1.13 & 68.84 & 0.40 & 0.48 & $2.41 / 9.0$ \\
\hline
\end{tabular}

${ }^{a} N, N$-Dimethylcyclohexylamine.

체를 발포시켰다. 발포된 MP-PUF 복합체는 상온에서 24시 간 숙성시킨 후에 밀도, 모폴로지, 독립기포율(closed cell content), 열전도율을 측정하고 열중량분석을 수행하였다. NCO index를 1.1로 동일하게 유지시키며 PUF와 MP-PUF 복합체 의 제조에 사용한 원료들의 조성비를 Table 2에 정리하였다. 발포제로 사용된 $\mathrm{H}_{2} \mathrm{O}$ 의 양은 2.3 9.0 php 범위에서 변화시 켰다. $\mathrm{H}_{2} \mathrm{O}$ 의 투입량에 따라 전체 반응물에 함유된 $\mathrm{OH}$ 당량 이 변하므로, $\mathrm{NCO}$ index를 1.1로 맞추기 위하여 PMDI의 투 입량을 조절하였다. 실리콘계 계면활성제(L-6900)는 $1.5 \mathrm{php}$, 촉매는 $1.8 \mathrm{php}$ 의 비율로 계산하여 투입하였다. MP는 폴리 아디페이트디올에 $5.0 \mathrm{wt} \%$ 의 함량으로 분산되어 있지만, 각 각의 조성에 따라 MP-PUF 복합체에 $1.13 \sim 1.72 \mathrm{wt} \%$ 함유되 어 있다. MP-PUF 복합체의 밀도는 ASTM D 1622 규격에 따라 $30 \mathrm{~mm} \times 30 \mathrm{~mm} \times 30 \mathrm{~mm}$ (가로×세로×두께) 크기의 시편을 5 개 만들어 평균값을 취하였다. MP-PUF 복합체 셀의 형상 과 크기는 주사전자현미경(SEM, FEL, inspect F50)을 사용 하여 측정하였으며, 열분해온도, 분해속도와 분해잔량 등을 알기 위하여 열중량분석(TGA, Perkin Elmer TGA7)을 질소 기류 하에서 수행하였다. TGA 분석 시편의 무게를 $10 \mathrm{mg}$ 으 로 고정하고 $10^{\circ} \mathrm{C} / \mathrm{min}$ 의 속도로 승온하며 $800^{\circ} \mathrm{C}$ 까지 분석 하였다. 열전도율기기(KEM, QTM-500)를 사용하여 열선법 으로 시편 3 개의 열전도율을 $25^{\circ} \mathrm{C}$ 에서 측정하여 평균값을 취하였다. 순수 PUF는 MP가 분산되지 않은 폴리아디페이트 디올을 사용한 것 외에 MP-PUF의 제조와 같은 조건에서 수 행하였으며, 모든 분석과 측정도 MP-PUF 측정 시와 같은 조 건에서 수행하였다.

\section{결과 및 토론}

단열제로서 폴리우레탄폼에게 요구되는 중요한 물성 중의
하나는 열전도율이다. 폴리우레탄폼의 열전도율과 관련이 있 는 인자로는 폴리우레탄폼의 모폴로지, 독립기포율 등이 있 다. 이들 인자와 PUF와 MP-PUF 복합체의 열전도율 사이의 관계를 다음에 정리하였다.

밀도. 폴리우레탄폼의 밀도는 폴리우레탄폼의 기계적 물성 및 열전도율과 밀접한 관계가 있다. Figure 1은 순수한 PUF 와 MP-PUF 복합체의 밀도가 발포제 $\left(\mathrm{H}_{2} \mathrm{O}\right)$ 투입량이 증가함 에 따라 감소하는 경향을 보여준다. 또한 같은 양의 발포제 $\left(\mathrm{H}_{2} \mathrm{O}\right)$ 를 투입하였을 때에 MP-PUF의 밀도가 PUF의 밀도보 다 높은 것을 보여 준다. 예로써, 발포제 함량이 $2.3 \mathrm{php}$ 일 때 MP-PUF의 밀도는 $0.051 \mathrm{~g} / \mathrm{cm}^{3}$ 로 PUF의 밀도 $0.032 \mathrm{~g} / \mathrm{cm}^{3}$ 보 다 약 1.6배 컸다. 그러나 $\mathrm{H}_{2} \mathrm{O}$ 투입량이 증가함에 따라 밀도

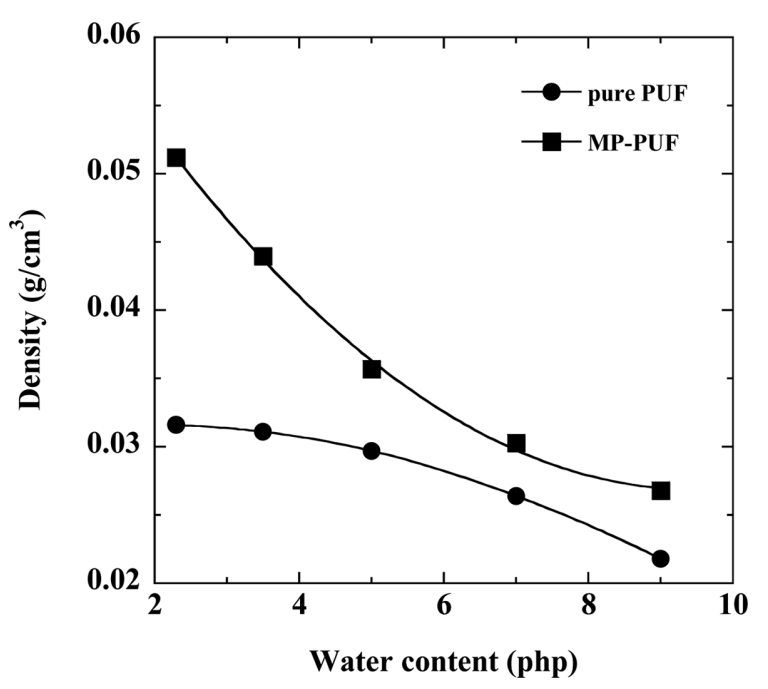

Figure 1. Density of PUFs and MP-PUFs $v s$. the blowing agent (water) content. The content of melamine phosphate of the MPPUFs was maintained at $1.43 \pm 0.30 \mathrm{wt} \%$. 
의 차이는 줄어들어서 $\mathrm{H}_{2} \mathrm{O} 9.0 \mathrm{php}$ 에서 PUF와 MP-PUF의 밀도는 각각 0.022 와 $0.027 \mathrm{~g} / \mathrm{cm}^{3}$ 로 큰 차이를 보이지 않았 다. Figure 1 은 $\mathrm{H}_{2} \mathrm{O}$ 투입량이 증가함에 따라 MP-PUF의 밀 도가 감소하는 정도가 PUF 밀도가 감소하는 정도보다 큰 것 을 보여준다.

PUF와 MP-PUF의 밀도는 폼의 단위 부피를 구성하는 성 분에 크게 좌우된다. 우레탄폼의 부피는 셀의 골격을 유지하 는 고형분과 셀의 내부 공간을 채우는 기체로 이루어져 있 다. 고형분의 분율(또는 기체의 분율)뿐만 아니라, 셀을 채우 는 기체의 조성을 결정하는 독립기포율도 우레탄폼의 밀도에 직접적으로 영향을 준다. 본 연구에서는 밀도보다는 밀도에 영향을 주는 셀의 크기와 구조, 독립기포율 등으로 세분화하 여 이들이 폴리우레탄폼의 열전도율에 주는 영향을 기술하였다.

MF-PUF의 열전도율. PUF의 셀의 크기와 구조, 독립기포 율은 폴리우레탄의 열전도율에 크게 영향을 준다. Figure 2는 순수 PUF와 MP-PUF의 모폴로지를 보여주는 SEM 사진으 로, 순수 PUF와 MP-PUF 모두 발포제 $\left(\mathrm{H}_{2} \mathrm{O}\right)$ 함량이 증가함 에 따라 셀의 크기가 커지는 것을 알 수 있다. 또한 발포제 $\left(\mathrm{H}_{2} \mathrm{O}\right)$ 함량이 같을 때에, MP-PUF의 셀 크기는 순수 PUF보 다 작은 것을 보여준다. MP-PUF의 셀 크기가 PUF 셀보다 작은 이유는 $\mathrm{H}_{2} \mathrm{O}$ 와 $\mathrm{PMDI}$ 가 반응하여 생성된 이산화탄소가 팽창하고 확산하는 것을 MP가 방해하기 때문이라 추정된다. PUF와 MP-PUF의 셀 크기 차이를 확인하기 위하여 SEM 사 진에 있는 PUF 셀들의 크기를 측정하고 평균값을 취하여 Figure 3에 나타내었다. Figure 3은 발포제 $\left(\mathrm{H}_{2} \mathrm{O}\right)$ 함량이 증가 함에 따라 PUF와 MP-PUF의 셀 직경이 커지며, 또한 PUF 셀 직경의 증가 정도가 MP-PUF의 셀 직경이 증가하는 정도 보다 큰 것을 보여준다. 순수 PUF와 MP-PUF 사이에서 셀 의 크기 차이는 발포제 $\left(\mathrm{H}_{2} \mathrm{O}\right)$ 함량이 $2.3,3.5,5.0 \mathrm{php}$ 일 때에 각각 $83,94,106 \mu \mathrm{m}$ 로 점차 증가하였다. 그러나 발포제 $\left(\mathrm{H}_{2} \mathrm{O}\right)$ 함량이 $9.0 \mathrm{php}$ 일 때에 MP-PUF의 셀은 시간이 지남

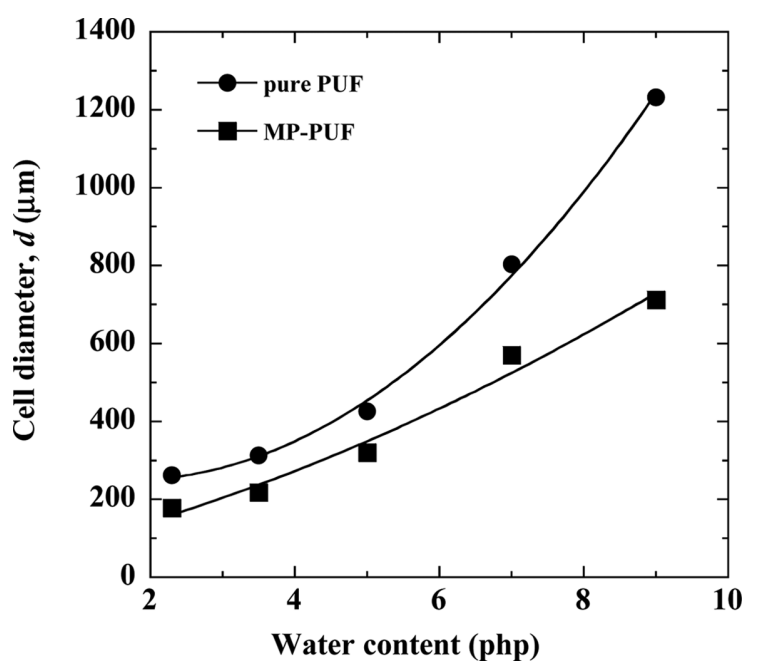

Figure 3. Cell diameter of the pure PUFs (-) and the MP-PUFs (ם) $v s . \mathrm{H}_{2} \mathrm{O}$ (blowin agent) content. The content of melamine phosphate of the MP-PUFs was maintained at $1.43 \pm 0.30 \mathrm{wt} \%$.

에 따라 수축되어서 순수 PUF의 셀 직경과의 차이가 $520 \mu \mathrm{m}$ 로 크게 증가하였다. PUF의 셀 크기가 발포제 $\left(\mathrm{H}_{2} \mathrm{O}\right)$ 투입량 에 대하여 2차 함수적으로 증가하는 것은 $\mathrm{H}_{2} \mathrm{O}$ 투입량이 증 가함에 따라 발포기체 $\left(\mathrm{CO}_{2}\right)$ 의 양이 증가하고, 따라서 $\mathrm{CO}_{2}$ 기 포의 크기가 커지고 서로 응집되기 때문이다. Figure 2의 SEM 사진과 Figure 3에 나타난 셀 직경의 변화는 이러한 경향을 잘 보여준다. Figure 1에서 $\mathrm{H}_{2} \mathrm{O}$ 투입량이 증가함에 따라 순 수 PUF의 밀도가 빠르게 낮아지나, MP-PUF의 밀도가 감소 하는 정도가 완화되는 것은 순수 PUF에서 $\mathrm{CO}_{2}$ 기포의 성장 과 응집이 순조롭게 이루어지는 반면에, $\mathrm{H}_{2} \mathrm{O}$ 투입량이 $7 \mathrm{php}$ 보다 커지면 MP-PUF에서 셀의 수축이 일어나는 결과가 반 영된 것이라 할 수 있다.

폴리우레탄폼의 단열 효과는 폴리우레탄폼의 셀을 채우고
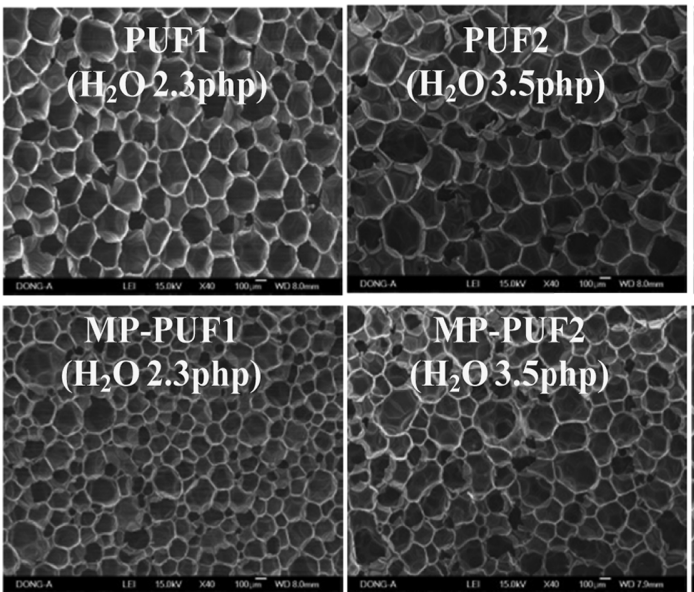
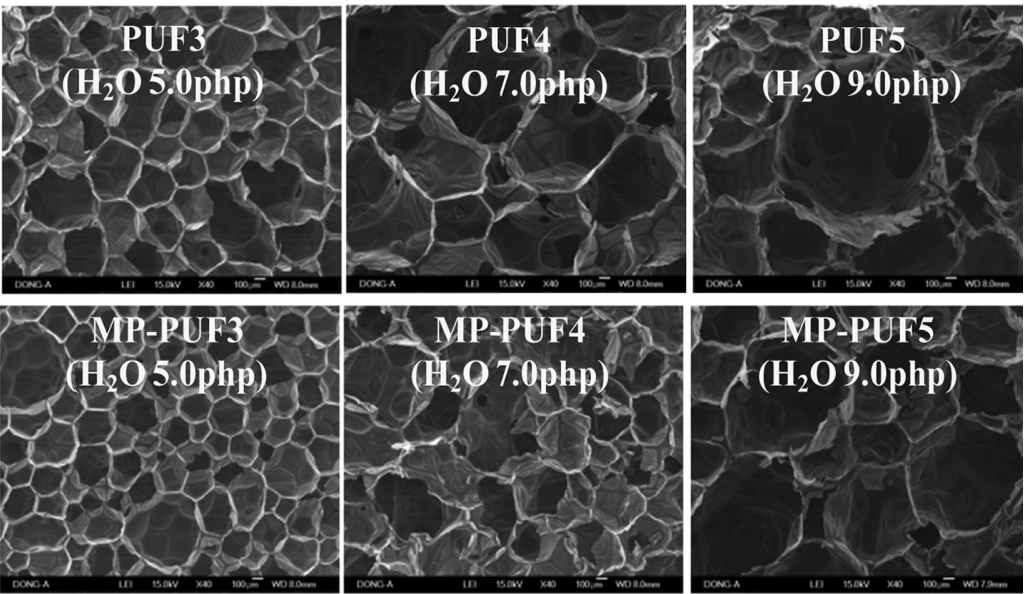
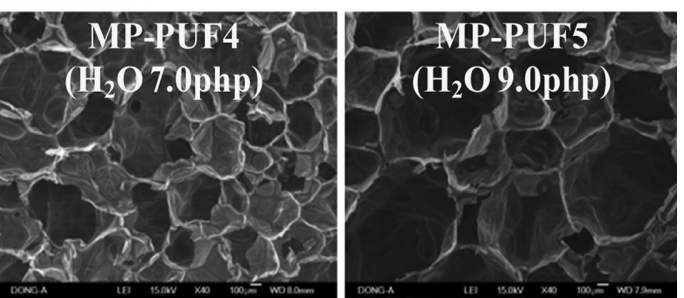

Figure 2. SEM images of pure polyurethane foams (PUF1 5) and melamine phosphate-polyurethane composite foams (MP-PUF1 5). 
있는 고형분, 기체들의 분율과 그들의 열전도율에 의하여 영 향을 받는다. 고형분인 폴리우레탄과 $\mathrm{MP}$ 의 열전도율은 기체 의 열전도율에 비하여 매우 크다. 폴리우레탄폼의 셀 직경을 크게 만들어 폴리우레탄폼의 단위길이 당 셀의 수를 줄이면 셀의 경계면을 구성하는 우레탄과 $\mathrm{MP}$ 의 분율이 감소하고, 따 라서 열전도율이 작아지는 것을 예상할 수 있다. Figure 4는 발포제 $\left(\mathrm{H}_{2} \mathrm{O}\right)$ 투입량을 2.3 9.0 php로 변화시키며 제조한 PUF 시료들의 열전도율이 MP-PUF의 열전도율보다 작은 것을 보 여준다. MP-PUF에 비하여 PUF의 열전도율이 작은 원인 중 의 하나는 PUF의 셀 직경이 MP-PUF 복합체의 셀 직경보다 커서(Figure 3 참조), 단위길이 당 고형분의 분율이 MP-PUF 복합체에 비하여 작기 때문이다. PUF의 셀 크기가 큰 것 이 외에도, PUF가 MP-PUF에 비하여 closed cell 구조를 더 많 이 가진 것도 PUF의 열전도율을 낮추는 요인이다. Table 3 에 PUF와 MP-PUF의 독립기포율 측정 결과를 정리하였다. 발포제 $\left(\mathrm{H}_{2} \mathrm{O}\right)$ 투입량이 2.3 7.0 php 사이에서, 순수한 PUF 셀

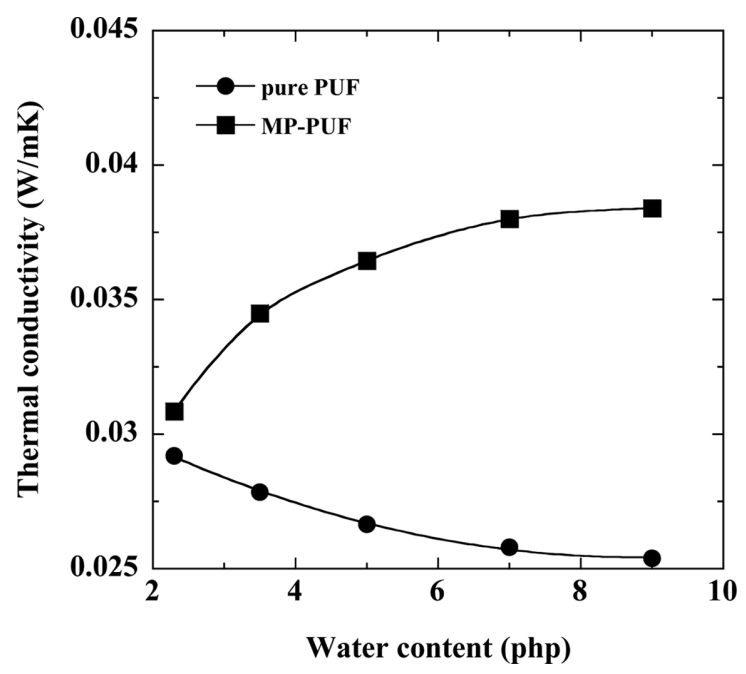

Figure 4. Thermal conductivity of the pure PUFs $(\bullet)$ and the MPPUFs (ם) vs. water (blowing agent) content: The content of melamine phosphate of the MP-PUFs was maintained at $1.43 \pm 0.30 \mathrm{wt} \%$.

Table 3. Close Cell Content of the Pure PUFs and the MPPUFs

\begin{tabular}{ccccc}
\hline \multirow{2}{*}{$\begin{array}{c}\mathrm{H}_{2} \mathrm{O} \text { content } \\
\text { (php) }\end{array}$} & \multicolumn{2}{c}{ Close cell content (\%) } & \multicolumn{2}{c}{ Mole fraction of $\mathrm{CO}_{2}{ }^{a}$} \\
\cline { 2 - 5 } & pure PUF & MP-PUF & pure PUF & MP-PUF \\
\hline 2.3 & 94.7 & 61.8 & 0.9473 & 0.6196 \\
5.0 & 93.1 & 58.7 & 0.9314 & 0.5887 \\
7.0 & 92.8 & 57.9 & 0.9285 & 0.5807 \\
\hline
\end{tabular}

${ }^{a}$ The mole fractions of $\mathrm{CO}_{2}$ in the pure PUF and MP-PUF were calculated at 1 bar and $25^{\circ} \mathrm{C}$, based on the assumption that the polyurethane forms were composed of only closed cells and open cells. The volume of closed and open cells was filled with $\mathrm{CO}_{2}$ and air, respectively.
의 독립기포율은 92.8 94.7\%인 반면에, MP-PUF의 독립기포 율은 57.9 61.8\%로 셀의 상당량이 open cell 구조였다. MP$\mathrm{PUF}$ 의 독립기포율이 낮은 이유는 발포 과정에서 생성된 $\mathrm{CO}_{2}$ 기포가 성장할 때에, 고체 입자인 MP가 기포의 외부계면을 깨기 때문이다. 1 기압, 상온에서, $\mathrm{CO}_{2}$ 의 열전도율 $(0.0157 \mathrm{~W} /$ $\mathrm{mK} @ 1$ bar, $10^{\circ} \mathrm{C}, 0.0184 \mathrm{~W} / \mathrm{mK} @ 1$ bar, $\left.50{ }^{\circ} \mathrm{C}\right)$ 은 공기 열전도율 $\left(0.0250 \mathrm{~W} / \mathrm{mK} @ 1 \mathrm{bar}, 10^{\circ} \mathrm{C}, 0.0282 \mathrm{~W} / \mathrm{mK} @ 1\right.$ $\mathrm{bar}, 50{ }^{\circ} \mathrm{C}$ )의 약 $64 \%$ 정도이므로, 셀 내부가 거의 $\mathrm{CO}_{2}$ 로 채 워진 PUF의 열전도율은 셀 부피의 약 $40 \%$ 가 공기로 충전된 MP-PUF의 열전도율 보다 작다.

Figure 4는 순수한 PUF의 열전도율이 $\mathrm{H}_{2} \mathrm{O}$ 투입량이 증가 함에 따라 조금씩 감소하는 경향도 보여준다. PUF의 열전도 율이 감소하는 현상은 PUF의 셀 크기와 독립기포율의 변화 로 설명할 수 있다. PUF의 독립기포율과 셀의 직경을 정리 한 Table 3과, Figure 3 을 재구성하여 작성한 Figure 5 는 $\mathrm{H}_{2} \mathrm{O}$ 투입량에 따라 변하는 셀의 직경과 독립기포율 값들을 보여 준다. $\mathrm{H}_{2} \mathrm{O}$ 투입량이 2.3에서 $7.0 \mathrm{php}$ 로 증가할 때에 순수 PUF 의 독립기포율은 94.7 에서 $92.8 \%$ 로 소폭 감소하였으나, 셀의 직경은 262에서 $803 \mu \mathrm{m}$ 로 약 3 배 증가하였다. 독립기포율의 감소는 $1.9 \%$ 로 작으므로, 이로부터 발생되는 PUF의 열전도 율 증가폭도 미미할 것이다. 그러나 PUF의 셀 직경이 3배로 증가함에 따라 단위길이 당 고형분의 분율은 낮아지고 기체 의 분율이 크게 증가하므로, PUF의 열전도율은 독립기포율 의 감소에도 불구하고 낮아진다.

PUF와 대조적으로, MP-PUF의 열전도율은 $\mathrm{H}_{2} \mathrm{O}$ 투입량과 함께 증가하였다. Figure 4는 MP-PUF의 열전도율이 $\mathrm{H}_{2} \mathrm{O}$ 투 입량이 $5.0 \mathrm{php}$ 이하에서 $\mathrm{H}_{2} \mathrm{O}$ 양과 함께 급격히 커지나, $\mathrm{H}_{2} \mathrm{O}$ 함량이 $5.0 \mathrm{php}$ 보다 커지면 열전도율의 증가 추세는 완화되

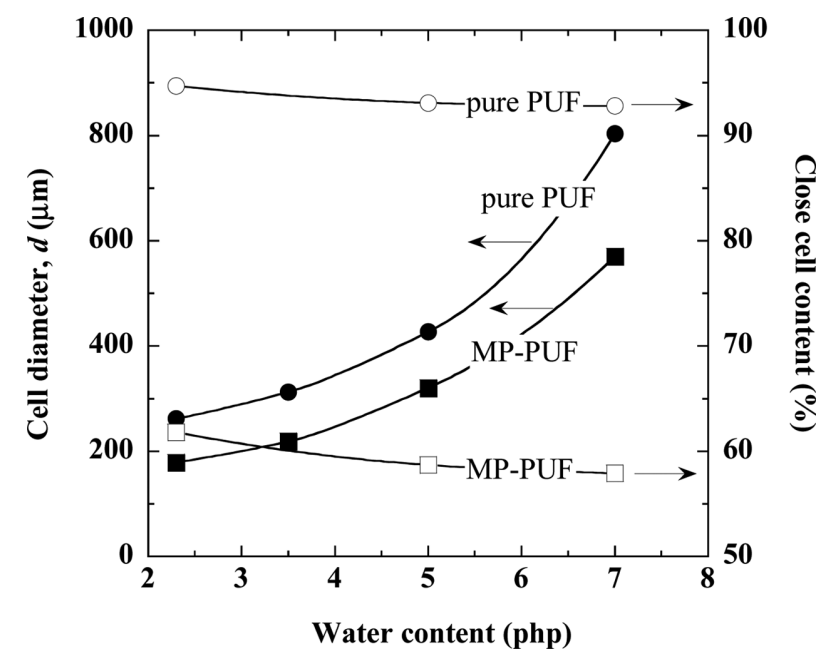

Figure 5. Cell diameter of the pure PUFs and the MP-PUFs vs. $\mathrm{H}_{2} \mathrm{O}$ (blowin agent) content. The content of melamine phosphate of the MP-PUFs was maintained at $1.43 \pm 0.30 \mathrm{wt} \%$. 
고, $\mathrm{H}_{2} \mathrm{O}$ 함량이 7.0 9.0 php로 더 커지면 열전도율의 변화가 미미한 것을 보여준다. 이 현상은 MP-PUF에 형성된 셀의 상 당수가 open cell 구조를 가진 것과 관련이 있다. MP-PUF의 독립기포율은 $\mathrm{H}_{2} \mathrm{O}$ 투입량이 2.3 에서 $7.0 \mathrm{php}$ 로 증가할 때에 61.8 에서 $57.9 \%$ 로 $3.9 \%$ 감소하였다. 이 감소폭은 $\mathrm{H}_{2} \mathrm{O}$ 투입 량의 변화가 같은 경우에, PUF의 독립기포율이 $1.9 \%$ 감소한 것에 비하여 약 2 배 정도 크다. 따라서 MP-PUF에서 open cello이 차지하는 부피도 같은 비율로 증가한다. 열전도율이 작 은 $\mathrm{CO}_{2}$ 의 분율 감소와 열전도율이 큰 공기의 분율 증가는 MP-PUF 복합체의 열전도율을 높이는 방향으로 작용한다. Table 3과 Figure 5 로부터, MP-PUF의 독립기포율이 감소하 는 정도는 $\mathrm{H}_{2} \mathrm{O}$ 투입량이 큰 영역에 비하여 적은 영역에서 큰 것을 알 수 있다. 이는 open cell의 부피가 $\mathrm{H}_{2} \mathrm{O}$ 투입량이 적 은 영역에서 비교적 빠르게 증가하다가, $\mathrm{H}_{2} \mathrm{O}$ 투입량이 커짐 에 따라 open cell의 부피 증가가 완화되는 것을 의미한다. 그 러므로 MP-PUF의 열전도율은 $\mathrm{H}_{2} \mathrm{O}$ 투입량이 적은 영역에서 는 $\mathrm{H}_{2} \mathrm{O}$ 양이 증가함에 따라 급격히 증가하다가 $\mathrm{H}_{2} \mathrm{O}$ 양이 커 지면 증가 정도가 작아진다. Figure 4는 MP-PUF의 열전도율 이 $\mathrm{H}_{2} \mathrm{O}$ 투입량에 대하여 근호함수의 형태로 증가하는 거동 을 잘 보여주고 있다. 이런 거동으로부터 MP-PUF의 열전도 율 변화를 다음과 같이 해석할 수 있다. MP-PUF의 open cell 함량은 $40 \%$ 로 상당히 높을 뿐만 아니라 open cell을 채우고 있는 공기의 열전도율은 $\mathrm{CO}_{2}$ 의 1.6 배 정도로 높다. 이 2 가지 요인에 의하여 MP-PUF의 열전도율이 증가되는 정도가 $\mathrm{H}_{2} \mathrm{O}$ 투입량에 따라 커진 기체분율이 MP-PUF의 열전도율을 감소 시키는 효과를 압도하였다.

폴리우레탄폼의 셀 골격을 이루고 있는 고형분은 열전도율 이 높으나, 우레탄폼의 대부분이 기체로 이루어져 있으므로 PUF와 MP-PUF의 열전도율에 주는 영향은 작을 것이다. 그 러나 PUF와 MP-PUF의 셀 직경이 작아지며 고형분의 무게 분율이 늘어남에 따라, 고형분이 PUF와 MP-PUF의 열전도 율에 주는 영향은 커질 것이다. $\mathrm{H}_{2} \mathrm{O}$ 투입량이 $2.3 \mathrm{php}$ 일 때 에, PUF의 셀 직경과 독립기포율은 MP-PUF의 셀 직경과 독 립기포율의 1.5 배이고, 밀도는 0.6 배 정도이다. 이렇게 큰 차 이에도 불구하고, PUF와 MP-PUF의 열전도율 차이는 $5 \%$ 정 도로 미미하다(Figure 4 참조). 이는 열전도율이 높은 고형분 의 분율이 셀의 크기가 작아짐에 따라 증가하므로, $\mathrm{H}_{2} \mathrm{O}$ 투 입량이 적은 영역에서 PUF와 MP-PUF의 열전도율은 셀을 채운 기체의 열전도율보다 고형분의 열전도율에 더 큰 영향 을 받기 때문이다. PUF와 MP-PUF에서 고형분의 분율이 낮 아지고 기체의 분율이 높아지면, 셀의 크기와 독립기포율이 전체 열전도율에 주는 영향이 커질 것이다. 비록 본 논문에 서 시도되지 않았으나, Table 2의 자료와 Figures 1, 4, 5 에 나타난 물성 측정 결과를 연관시켜 해석하면 셀크기와 관련 된 단위부피 당 고형분 또는 기체의 분율과 독립기포율이 PUF와 MP-PUF의 열전도율에 주는 영향을 정량적으로 확인
할 수 있으리라 기대된다.

열중량 분석. Figure 6(a)는 $\mathrm{H}_{2} \mathrm{O}$ 투입량을 변화시키며 제 조한 PUF 시료들의 열분해 온도와 무게 변화를 질소에서 측 정한 TGA 결과이다. PUF의 1 차 열분해는 약 $250^{\circ} \mathrm{C}$ 에서 시 작되어 $350{ }^{\circ} \mathrm{C}$ 까지 급격히 진행되었다. 연구자에 따라 온도 범위에 다소 차이는 있지만, 폴리우레탄폼의 1 차 열분해는 약 $250 \sim 380^{\circ} \mathrm{C}$ 에서 관측되며, 이 과정에서 우레탄기가 이소시아 네이트, 알코올, 아민, $\mathrm{CO}_{2}$ 등으로 분해되며 급격한 무게 감 소가 일어난다고 알려져 있다. ${ }^{5,11,12} \mathrm{PUF}$ 시료들의 열분해는 $350{ }^{\circ} \mathrm{C}$ 부터 속도가 줄어들어 약 $550^{\circ} \mathrm{C}$ 까지 완만하게 진행되 다가, 그 이상의 온도에서 분해속도가 약간 증가하였다. Table 4에 PUF와 MP-PUF 시료들의 분해 후 잔량을 정리하였다.

Figure $6(\mathrm{a})$ 는 $700^{\circ} \mathrm{C}$ 까지 열분해가 이루어진 후에, PUF5
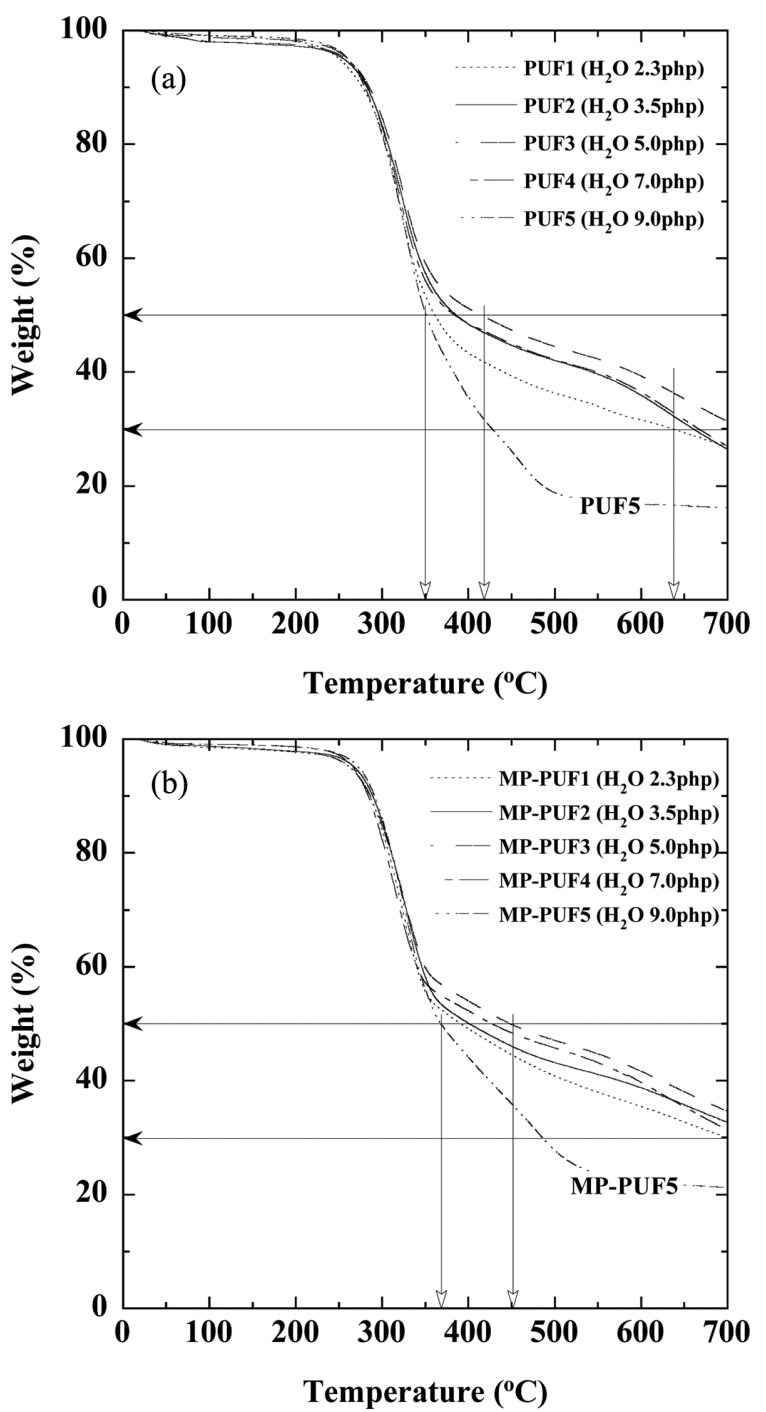

Figure 6. TGA curves of the PUF samples: (a) pure PUFs samples; (b) MP-PUFs samples. The content of melamine phosphate of the MP-PUFs was maintained at $1.43 \pm 0.30 \mathrm{wt} \%$. 
Table 4. Residual Weight of the PUFs and MP-PUFs at Various Temperatures

\begin{tabular}{|c|c|c|c|c|c|c|c|}
\hline \multirow{2}{*}{$\begin{array}{l}\text { Sample } \\
\text { No. }\end{array}$} & \multirow{2}{*}{$\begin{array}{l}\mathrm{H}_{2} \mathrm{O} \\
(\mathrm{php})\end{array}$} & \multirow{2}{*}{$\begin{array}{c}\text { Melamine } \\
\text { phosphate (wt\%) }\end{array}$} & \multicolumn{5}{|c|}{$\mathrm{wt} \%$ of Residue mass } \\
\hline & & & at $350^{\circ} \mathrm{C}$ & at $400{ }^{\circ} \mathrm{C}$ & at $500{ }^{\circ} \mathrm{C}$ & at $600{ }^{\circ} \mathrm{C}$ & at $700^{\circ} \mathrm{C}$ \\
\hline PUF1 & 2.3 & - & 53.5 & 43.3 & 36.3 & 31.6 & 26.9 \\
\hline PUF2 & 3.5 & - & 57.4 & 48.4 & 42.1 & 35.9 & 26.4 \\
\hline PUF3 & 5.0 & - & 59.2 & 51.2 & 44.5 & 39.3 & 31.4 \\
\hline PUF4 & 7.0 & - & 56.1 & 48.6 & 42.2 & 36.5 & 27.0 \\
\hline PUF5 & 9.0 & - & 50.4 & 35.4 & 18.8 & 16.8 & 16.2 \\
\hline MP-PUF1 & 2.3 & 1.72 & 55.7 & 49.1 & 40.9 & 35.5 & 29.9 \\
\hline MP-PUF2 & 3.5 & 1.58 & 58.3 & 50.1 & 43.2 & 38.8 & 32.7 \\
\hline MP-PUF3 & 5.0 & 1.42 & 59.9 & 54.0 & 47.1 & 41.7 & 34.6 \\
\hline MP-PUF4 & 7.0 & 1.26 & 57.2 & 52.3 & 45.8 & 39.7 & 31.4 \\
\hline MP-PUF5 & 9.0 & 1.13 & 56.1 & 44.1 & 27.7 & 22.1 & 21.3 \\
\hline
\end{tabular}

를 제외한 PUF1 4의 잔량이 27 32\% 남아 있는 것을 보여준 다. 일반적으로 폴리우레탄폼의 2 차 열분해는 $450 \sim 600{ }^{\circ} \mathrm{C}$ 에 서 일어난다고 보고되고 있으며, $600{ }^{\circ} \mathrm{C}$ 보다 높은 온도에서 열분해 잔량이 $10 \%$ 미만으로 알려져 있다. $5,11,12$ 위의 문헌에 서 보고된 열분해 잔량과 비교하면, PUF1 5 시료들은 고온 에서도 상당량의 잔량이 남아있다. Shufen 등과 ${ }^{11}$ Thirumal 등은 ${ }^{12}$ 폴리우레탄의 1 차 열분해 시에 생성된 이소시아네이 트기가 dimerization되는 과정에서 $\mathrm{CO}_{2}$ 가 빠져나오며 carbodiimide 화합물로 변환되고, 이 화합물이 알콜 또는 수증기와 반응하여 생성된 우레아 화합물은 1 차 열분해 온도에서도 본 래의 구조를 유지하다가 $450{ }^{\circ} \mathrm{C}$ 보다 높은 온도에서 2 차 열분 해가 본격적으로 시작된다고 보고하였다. 이들의 연구 결과 를 참조하면, 본 연구에서 제조한 PUF 시료들이 고온에서 안 정한 이유는 비교적 과량으로 사용한 $\mathrm{H}_{2} \mathrm{O}$ 가 이소시아네이트 와 반응하며 우레아기를 다량으로 생성시켰기 때문이라 할 수 있다.

Figure 6(b)는 MP-PUF의 열분해 과정이 전반적으로 PUF 의 열분해와 비슷하게 진행되는 것을 보여준다. MP-PUF의 1 차 열분해가 급격하게 시작되는 온도는 PUF의 분해가 시작 되는 온도와 비슷하다. 그러나 MP-PUF1 4 시료들의 1차 열 분해가 종료되는 온도는 PUF1 4 시료들에 비하여 높으며, 분해 잔량도 더 많았다. Figure 6(a)와 (b)를 보면 MP-PUF1 4 시료들의 분해 잔량이 $50 \%$ 가 되는 온도가 $370 ~ 450{ }^{\circ} \mathrm{C}$ 로 PUF1 4 시료들에 비하여 $20 \sim 30{ }^{\circ} \mathrm{C}$ 높은 것을 알 수 있다. 이 와 같이 MP-PUF의 열안정성이 향상되는 이유는 MP가 heat $\operatorname{sink}$ 와 barrier로 작용하였기 때문이다. $\mathrm{MP}$ 는 $200{ }^{\circ} \mathrm{C}$ 부터 melamine pyro-phosphate로 변형되며, 이어서 $260^{\circ} \mathrm{C}$ 에서 melamine polyphosphate(MPP)가 되고, MPP가 $350^{\circ} \mathrm{C}$ 에서 분해하는 과정에서 열을 흡수하는 heat sink 역할을 하는 것 은 잘 알려져 있다. ${ }^{13}$ 또한 $\mathrm{MP}, \mathrm{MPP}$ 는 고온에서 분해되는 과
정에서 char를 형성하여 heat barrier로서 우수한 난연효과를 발현하는 것으로 알려져 있다. ${ }^{14-16}$ 분해 잔량이 $30 \%$ 가 되는 온도를 비교하면, PUF1의 경우에 $640{ }^{\circ} \mathrm{C}$ 인 반면에 PUF1에 대응되는 MP-PUF 1 는 약 $700{ }^{\circ} \mathrm{C}$ 로, $70{ }^{\circ} \mathrm{C}$ 이상 높아졌다. MPPUF1 이외에도, PUF2 5에 대응되는 모든 MP-PUF2 5 시료 에서 유사한 열안정성의 향상이 관측되었다. 고온영역에서 MP-PUF 시료들의 열안정성이 크게 향상되는 것은 1 차 열분 해 과정에서 생성된 우레아 화합물과 melamine phosphate의 분해 지연 효과가 상승작용을 발현하였기 때문이라 할 수 있다.

Figure 6의 $300 \sim 700{ }^{\circ} \mathrm{C}$ 영역을 확대한 Figure 7은 PUF와 MP-PUF 시료들의 분해 잔량이 우레탄폼 제조과정에서 투입 한 $\mathrm{H}_{2} \mathrm{O}$ 의 양에 단순하게 비례하지 않는 것을 보여준다. $\mathrm{H}_{2} \mathrm{O}$ 투입량이 2.3, 3.5, $5.0 \mathrm{php}$ 로 증가함에 따라 분해 잔량은 많 아졌으나, $\mathrm{H}_{2} \mathrm{O}$ 투입량이 $7.0 \mathrm{php}$ 로 더 증가함에 따라 분해 잔량이 감소하기 시작하였고, $\mathrm{H}_{2} \mathrm{O}$ 투입량이 $9.0 \mathrm{php}$ 일 때는 분해 잔량이 급격하게 감소하였다. $\mathrm{H}_{2} \mathrm{O}$ 투입량의 증가에 따 라, 분해 잔량이 급격히 증가하며 최대값을 가졌다가 급격히 감소하는 현상을 다음과 같이 설명할 수 있다. 2 차 열분해가 일어나는 온도영역에서 우레탄폼의 분해잔량은 1 차 열분해 과정에서 생성되는 우레아 화합물의 양에 비례할 것이므로, $\mathrm{H}_{2} \mathrm{O}$ 투입량이 증가할수록 우레아기가 많이 생성되고 따라서 분해 잔량은 증가할 것이다. 그러나 $\mathrm{H}_{2} \mathrm{O}$ 투입량이 증가함에 따라 PUF의 구성성분은 우레아 화합물을 생성할 수 있는 고 형분보다 $\mathrm{CO}_{2}$ 나 공기로 이루어지므로 분해 잔량은 감소할 것이다. $\mathrm{H}_{2} \mathrm{O}$ 투입량에 따라 PUF와 MP-PUF의 밀도(고형 분 함량)가 급격히 작아지는 것을 감안하면 $\mathrm{H}_{2} \mathrm{O}$ 투입량의 증가가 작음에도 불구하고 분해 잔량의 변화가 상당한 것은 이해할 만 하다. 또한 발포제인 $\mathrm{H}_{2} \mathrm{O}$ 투입량의 변화가 분해 잔량에 주는 영향은 PUF와 MP-PUF 복합체에도 동일할 것 이다. 

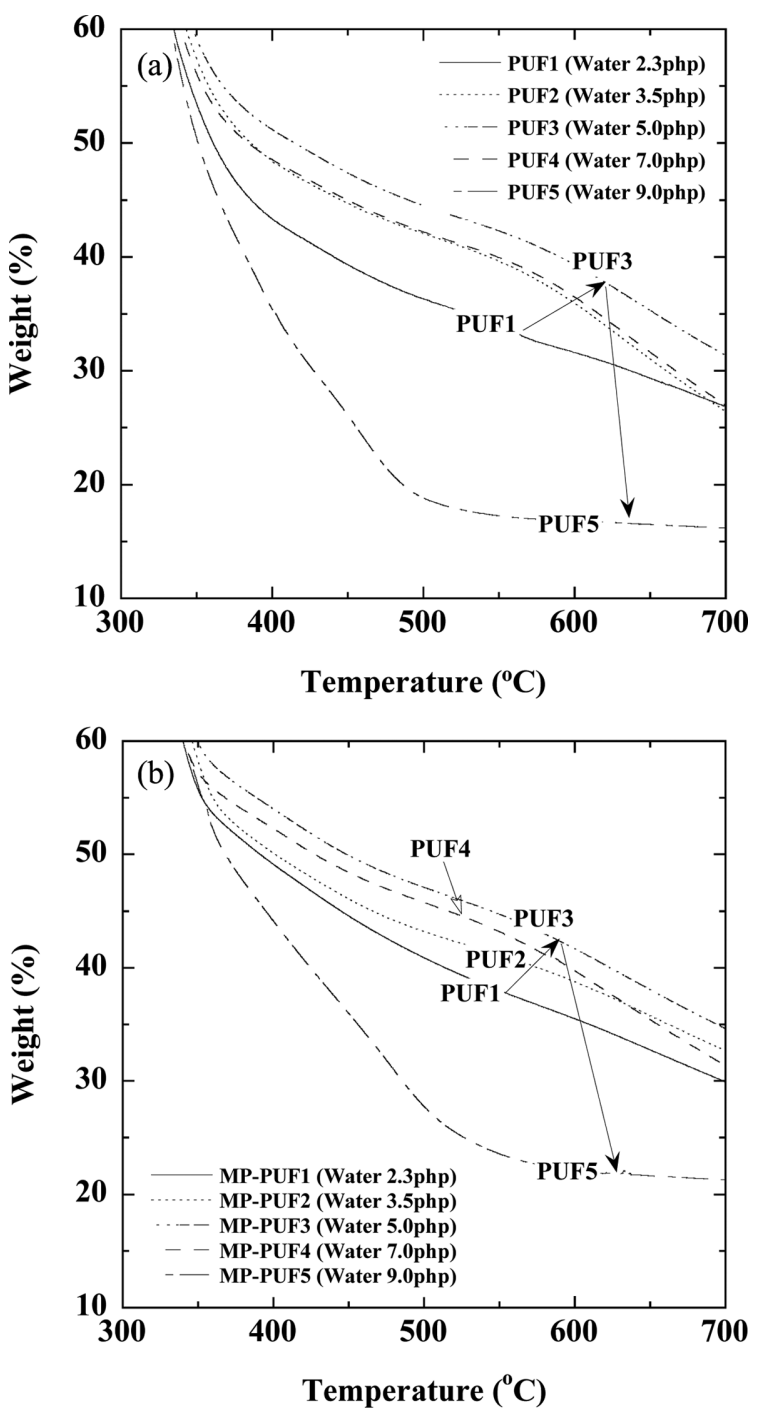

Figure 7. Enlarged view of Figure 6(a) and (b) represents the TGA curves of the PUF and the MP-PUF samples. The content of melamine phosphate of the MP-PUFs was maintained at $1.43 \pm$ $0.30 \mathrm{wt} \%$

\section{결 론}

$\mathrm{MP}$ 가 $1.43 \%$ 함유된 MP-PUF를 MP가 분산된 폴리아디페 이트디올과 폴리에테르-폴리올, PMDI를 주원료로, 발포제로 $\mathrm{H}_{2} \mathrm{O}$ 를 사용하여 제조하고 그 열적 특성을 연구하여 다음과 같은 결론을 얻었다.

매우 소량이지만 $\mathrm{MP}$ 의 첨가로 인하여, $\mathrm{PUF}$ 에 비하여 $\mathrm{MP}-$ PUF의 셀 크기가 작아지고 독립기포율이 92.8 94.7\%에서 $57.9 \sim 61.8 \%$ 로 크게 낮아짐에 따라, MP-PUF의 열전도율은 높아졌다. 이는 MP-PUF 셀의 빈 공간을 채우는 공기의 열 전도율이 높은 것이 주원인이다. MP-PUF의 독립기포율은
$\mathrm{H}_{2} \mathrm{O}$ 투입량이 증가함에 따라 낮아지므로, MP-PUF의 열전도 율은 $\mathrm{H}_{2} \mathrm{O}$ 양이 증가함에 따라 높아진다. MP-PUF의 열전도 율은 셀 크기(따라서 기체 분율 또는 고형분 분율)와 독립기 포율에 의하여 크게 영향을 받으며, 이 두 인자 사이에서 우 세한 인자에 의하여 결정되는 것으로 추정된다.

MP로 인하여 MP-PUF의 열안정성은 순수한 PUF에 비하 여 향상되며, 특히 2 차 열분해가 일어나는 $450{ }^{\circ} \mathrm{C}$ 이상의 고 온에서 현저하게 개선된다. 이러한 MP-PUF의 고온 열안정 성은 MP의 heat sink와 heat barrier 효과와 함께, 발포 과정 에서 생성된 우레아기와 우레탄기의 1 차 열분해 시에 생성되 는 우레아기의 분해가 $450{ }^{\circ} \mathrm{C}$ 이상의 고온에서 시작되므로 열분해가 지연되기 때문이다.

감사의 글: 이 논문은 동아대학교 교내연구비 지원에 의하 여 연구되었음.

\section{참 고 문 헌}

1. S. S. Kim and J. N. Park, Polym. Sci. Tech., 10, 614 (1999).

2. U. Jarfelt and O. Ramnas, The 10th International Symposium on District Heating and Cooling, September 3-5, Hanover (2006).

3. H. Lim, S. H. Kim, and B. K. Kim, J. Appl. Polym. Sci., 110, 49 (2008).

4. H. Lim, S. H. Kim, and B. K. Kim, Polym. Adv. Technol., 19, 1729 (2008)

5. S. H. Kim, M. C. Lee, H. D. Kim, H. C. Park, H. M. Jeong, K. S. Yoon, and B. K. Kim, J. Appl. Polym. Sci., 117, 1992 (2010).

6. W. J. Seo, Y. T. Sung, S. B. Kim, K. H. Choe, J. Y. Sung, and W. N. Kim, J. Appl. Polym. Sci., 102, 3764 (2006).

7. M. C. Saha, Md. E. Kabir, and S. Jeelani, Mater. Sci. Eng. A, 479, 213 (2008).

8. C. B. Kim, W. J. Seo, O. D. Kwon, and S. B. Kim, Appl. Chem. Eng., 22, 540 (2011).

9. A. Lorenzetti, M. Modesti, S. Besco, D. Hrelja, and S. Danadi, Polym. Degrad. Stabil., 96, 1455 (2011).

10. K. K. Park and S. H. Lee, Elastom. Compos., 46, 343 (2011).

11. L. Shufen, J. Zhi, Y. Kaijun, and Y. Shuqin, Polym. Plast. Technol. Eng., 45, 95 (2006).

12. M. Thirumal, D. Khastgir, G. B. Nando, Y. P. Naik, and N. K. Singha, Polym. Degrad. Stabil., 95, 1138 (2010).

13. A. B. Morgan and C. A. Wilkie, Flame Retardant Polymer Nanocomposites, John Wiley \& Sons Inc, New Jersey, USA, 2007.

14. G. Camino, L. Costa, and G. Martinasso, Polym. Degrad. Stabil., 23, 359 (1989).

15. S. Bourbigot, M. L. Bras, R. Delobel, P. Brant, and J. M. Trmillon, Carbon, 33, 283 (1995).

16. S. Jahromi, W. Gabrielse, and A. Braam, Polymer, 44, 25 (2003). 